\title{
-
}

\section{A categoria da práxis em Pedagogia do Oprimido: sentidos e implicações para a educação libertadora*}

Sandra Maria Gadelha de Carvalho ${ }^{\mathrm{I}, \text { II }}$

Paulo Martins Pio ${ }^{\text {III, IV }}$

http://dx.doi.org/10.24109/2176-6681.rbep.98i249.2729

\section{Resumo}

Os ensaios freireanos encontrados em Pedagogia do Oprimido se concretizam na relação teórico-prática e inovam-se associando o conceito de práxis à educação, a qual está a serviço da libertação, fundada na criatividade, no diálogo, na reflexão, na conscientização e em ações dos homens sobre a realidade visando a sua transformação. Na perspectiva de contribuir para a reflexão sobre o vínculo entre práxis e educação, o presente estudo, teórico-bibliográfico, tem como principal propósito identificar e analisar os sentidos da categoria práxis na obra Pedagogia do Oprimido. Debruçando nosso olhar investigativo sobre a obra em questão e dialogando com os escritos de Sánchez Vázquez (1977), Marx (2007), Konder (1992), entre outros, observamos a preponderância, nos sentidos de práxis propiciados por Freire, do caráter político, possibilitador do processo de conscientização dos homens e orientador de suas ações sobre o mundo real com vistas à sua transformação. A práxis em Freire remete à ideia de um conjunto de práticas visando à transformação da realidade e à produção da história. O que nos leva a crer que é sobre o tripé formado pela transformação de uma realidade injusta, pela transformação baseada na crítica dessa realidade e pelo seu conhecimento que Freire, a exemplo de Sánchez Vázquez (1977), elabora uma noção de práxis histórica e social.

Palavras-chave: educação libertadora; práxis; Pedagogia do Oprimido. 


\section{Abstract}

The category of praxis in Pedagogy of the Oppressed: meanings and implications for a libertarian education

The essays of Paulo Freire's Pedagogy of the Oppressed come to life in the connection between theory and practice and they innovate by associating the concept of praxis to the field of education. In turn, education is employed as a mean to reach freedom, based on creativity, reflection, awareness, and people's attitudes towards real life, and striving to transform it. Adding to the discussion vis-à-vis the connection between praxis and education, this theoretical and bibliographic paper intends mainly to identify and analyze the meanings assumed by the category of praxis in Pedagogy of the Oppressed. Scrutinizing Freire's book and dialoguing with the works of Sánchez Vázquez (1977), Marx (2007), Konder (1992), among others, the predominance of the political nature in the meanings of praxis offered by Freire is made visible; this political nature of the concept enables the consciousness-raising process and guides people's attitudes towards the real world, aiming at changing it. Praxis in Freire's conception invokes the idea of a set of practices that focus on altering reality and on creating history. Ultimately, this study suggests that Freire, based on Vazquez (1977), crafted a notion of social and historical praxis that is supported by a tripod that includes the transformation of an unjust reality, the transformation motivated on the critical view of said reality, and also the knowledge of said nature.

Keywords: libertarian education; praxis; Pedagogy of the Oppressed.

\section{O contexto de Freire}

Partindo do pensamento freireano de que a leitura de um texto demanda o conhecimento do contexto social a que se refere, concebemos como enriquecedor e importante iniciar este artigo revisitando o plano de fundo histórico-social em que Pedagogia do Oprimido foi escrito e descrevendo sucintamente a proposta educativa da obra em análise.

Nascido em 1921, o pernambucano Paulo Reglus Freire vivenciou os reflexos da crise econômica de 1929, conhecendo a pobreza e a fome. Com os esforços de sua mãe, conseguiu uma bolsa de estudos em Recife, capital pernambucana. Cursou a faculdade de direito, mas não exerceu a advocacia (Gadotti, 1996; Souza, 2001).

Em 1947, Freire teve contato com a educação de adultos, nas Zonas dos Mocambos, em Pernambuco. Juntamente com as professoras, elaborou críticas aos métodos da época baseados em cartilhas infantilizadas que não valorizavam os saberes resultantes das experiências desses indivíduos. Defendeu a necessidade de uma educação de adultos fundamentada na consciência da realidade por parte dos alfabetizandos, no conhecimento 
de si próprio e dos problemas sociais que os afligem e combateu a ideia de educação reduzida ao ato de conhecer e identificar letras, palavras e frases (Gadotti, 1996).

No início dos anos de 1960, Freire, com estudantes, educadores e outras pessoas preocupadas com a promoção da educação das classes populares e com a tomada e elevação da consciência, funda o Movimento de Cultura Popular (MCP), em Recife. A pretensão era desenvolver uma proposta educativa genuinamente brasileira. "A prática que se buscou implementar visava aproximar a intelectualidade da população, travando um diálogo em que a disposição do intelectual era a de aprender com o povo, despindo-se de todo espírito assistencialista" (Saviani, 2007, p. 316).

O êxito do trabalho realizado pelo MCP de Recife, cuja experiência serviu de base para o pensamento desenvolvido por Freire, juntamente com os resultados obtidos em seus trabalhos no estado do Rio Grande do Norte, onde 300 trabalhadores foram alfabetizados em 45 dias, tornou-se peça publicitária da secretaria de educação daquele estado e impressionou profundamente a opinião pública. Em consequência, o trabalho de Freire ganhou projeção nacional, levando-o ao cargo de coordenador do Plano Nacional de Alfabetização, criado entre 1963 e 1964 (Beisiegel, 2010; Saviani, 2007).

Nesse cenário, o método Paulo Freire tornou-se referência entre os movimentos envolvidos na prática da educação popular no País. Por suas características, pela notável simplicidade, pela coerência entre as práticas cotidianas e as perspectivas teóricas e pela defesa da necessidade da conscientização das camadas populares, o método surge como instrumento de atuação para os diversos grupos e movimentos sociais envolvidos na luta por políticas educacionais voltadas para adolescentes, jovens e adultos iletrados e pela construção de uma sociedade brasileira mais justa (Beisiegel, 2010).

O percurso de vida de Freire, enquanto homem e educador, foi circunscrito pelo clima perverso e antidemocrático do regime militar que se abatia no Brasil. Com a deflagração do golpe militar em 1964, interromperam-se os trabalhos e reprimiu-se a mobilização que vinha sendo feita em torno da cultura e da educação popular (Brandão, 2007; Gadotti, 1996).

Durante esse período, dada sua ação política de alfabetizar conscientizando, Freire foi considerado subversivo, perseguido e exilado. No exílio, dedicou-se à redação de Pedagogia do Oprimido. Freire resgata e descreve no livro Pedagogia da esperança: um reencontro com a pedagogia do oprimido (1992) todo o processo que resultou na obra Pedagogia do Oprimido. Assim ele diz:

Foi vivendo a intensidade da experiência da sociedade chilena, da minha experiência naquela experiência, que me fazia re-pensar sempre a experiência brasileira, cuja memória viva trouxera comigo para o exílio, que escrevi a Pedagogia do Oprimido entre 1967 e 1968. (Freire, 1992, p. 27). 
As ideias presentes em Pedagogia do Oprimido, como o respeito pelas diferentes culturas, o respeito ao contexto em que se está inserido, e a crítica à invasão cultural, são elementos inicialmente experimentados por Freire no Brasil e intensamente vividos em suas experiências no exílio. Beisiegel (2010, p. 83-84) sugere que Paulo Freire escreveu esse livro "numa fase de inquietações intelectuais, de muito estudo e de intensa procura de novas e talvez mais abrangentes explicações para os desafios que encontrar a na prática educativa".

Diante da concepção tradicional de educação escolar, denominada por Freire de educação bancária, ${ }^{1}$ ele propõe a educação problematizadora que considera a essência humana dos educandos, impulsiona a problematização e compreensão da realidade, na perspectiva de uma sociabilidade fundada na práxis. A educação problematizadora implica um constante empenho na desmitificação e no ato de desvelamento da realidade. Ela se faz num "esforço permanente através do qual os homens vão percebendo, criticamente, como estão sendo no mundo com que e em que se acham" (Freire, 2013, p. 100).

Em Pedagogia do Oprimido, advoga-se uma concepção e prática de educação que parte de um contexto concreto, objetivando entendê-lo, atendê-lo e responder as suas necessidades. Advoga-se também que se parta simultaneamente da teoria como propiciadora desse entendimento profundo e crítico. Proposição esta já reveladora de práxis.

Paulo Freire apresenta uma pedagogia que tem como fonte geradora a desconstrução da "ordem" social injusta e opressora. Portanto, trata-se de uma proposta educativa forjada pela e na práxis vivida social e historicamente e que requer a inserção crítica das massas em sua realidade, em busca de sua transformação. Para Freire (2013, p. 52), um dos sentidos da práxis é "ação e reflexão dos homens sobre o mundo para transformá-lo".

Segundo o educador, a formação revolucionária, transformadora da ordem social, econômica e politicamente injusta, é possibilitada pela conscientização das massas populares por meio de um método pedagógico dialógico. "Dialógico porque vai da realidade à consciência, da consciência à realidade, em um movimento esclarecedor e transformador" (Gutiérrez, 1988, p. 108); trata-se de uma forma de investigar o pensamento dos homens referido à realidade, "investigar seu atuar sobre a realidade, que é a sua práxis" (Freire, 2013, p. 136).

Dessa forma, a teoria pedagógica de Paulo Freire, fundada no

1 Na perspectiva de Freire a educação bancária ou também depositária "se torna um ato de depositar, em que os educandos são os depositários e o educador o depositante" (Freire, 2013, p. 80). Os educandos, oriundos das classes oprimidas, são desrespeitados na sua condição humana, desumanizados em seus saberes e experiências diálogo, na reflexão e na ação transformadora da realidade, objetiva a construção coletiva da consciência crítica da humanidade mediante uma práxis libertadora e revolucionária. Portanto, a pedagogia freireana se concretiza na relação teoria-prática, inovando ao alocar o conceito de práxis, de tradição marxista, voltado para a análise do modo de produção capitalista, relacionando-o à educação e orientando-o à luta pela humanização, desalienação e afirmação dos homens, contribuindo, dessa forma, para o processo de emancipação humana. 
Diante desse esboço, debruçaremos, a seguir, o nosso olhar sobre os sentidos da práxis contidos em Pedagogia do Oprimido, na perspectiva de que este estudo propicie o fortalecimento da categoria da práxis como indispensável na compreensão do movimento do real, tendo como horizonte o construto de uma educação libertadora, direcionando nossas atividades cotidianas e práticas educativas para o rompimento com a lógica do excludente, opressora do capital, e todas as suas ideologias e pedagogias.

Esta pesquisa não só é um exercício de compreensão do entendimento de Freire sobre a citada categoria, como também é subsídio para os estudos acerca da relação entre filosofia e educação e apresenta contribuições para a reflexão do vínculo entre práxis e educação. Pois, afinal, defendemos que "a educação é práxis, do contrário não é educação" (Gutiérrez, 1988, p. 108).

\section{Sentidos freireanos da práxis}

A referência à práxis na obra Pedagogia do Oprimido é uma constante em todo seu corpo. Ao longo de seus quatro capítulos, é recorrente a evocação da práxis por parte do autor. O educador pernambucano, na busca por propiciar maior reflexão sobre a categoria em relevo, aplica-lhe conotações que, a nosso ver, objetivam colocá-la em destaque, explicar seu sentido e justificar sua amplitude dentro de sua proposta educativa.

Como se observa no conjunto de citações, Freire, na obra analisada, ora evoca a categoria da práxis de forma isolada, ora a utiliza de forma adjetivada: práxis libertadora, práxis autêntica, práxis revolucionária e práxis verdadeira. Para ele:

N̦ão basta saberem-se numa relação dialética com o opressor [...]. E preciso, enfatizemos, que se entreguem à práxis libertadora. (Freire, 2013, p. 49, grifo nosso).

O desvelamento do mundo e de si mesmas, na práxis autêntica, possibilita às massas populares a sua adesão. (Freire, 2013, p. 229, grifo nosso).

A práxis revolucionária somente pode opor-se à práxis das elites dominadoras. E é natural que assim seja, pois são quefazeres antagônicos. (Freire, 2013, p. 169, grifo nosso).

[...] através de uma práxis verdadeira superam o estado de objetos, como dominados, e assumem o de sujeito da história. (Freire, 2013, p. 216, grifo nosso).

Práxis que, sendo reflexão e ação verdadeiramente transformadora da realidade, é fonte de conhecimento reflexivo e criação. (Freire, 2013, p. 127, grifo nosso).

A alusão à práxis aparece pela primeira vez nessa obra, precisamente no capítulo destinado à justificativa da pedagogia do oprimido (capítulo 1), de uma forma bastante coerente com a educação problematizadora defendida por Freire. Antes de qualquer tentativa de definição, o educador cita a práxis em meio a questionamentos levantados acerca da situação econômica-social-cultural em que as massas populares se encontram. 
Quem, melhor que os oprimidos, se encontrará preparado para entender o significado terrível de uma sociedade opressora? Quem sentirá, melhor que eles, os efeitos da opressão? Quem, mais que eles, para ir compreendendo a necessidade da libertação? Libertação a que não chegarão pelo acaso, mas pela práxis de sua busca; pelo conhecimento e reconhecimento da necessidade de lutar por ela. (Freire, 2013, p. 43, grifo nosso).

No processo de busca pela libertação dos homens, Freire aloca a práxis como condição e fundamento da ação, da luta, no sentido de rompimento com a idealização, bem como de revelação do teor alienante imposto pela relação opressor/oprimido. Para Freire, é essencial que os oprimidos descubram o opressor e se organizem para lutar pela libertação deles, pela superação desse regime.

No entanto, o conhecimento e reconhecimento dessa relação dialética, por si só, não basta, não favorece o processo de busca por libertação. A descoberta não pode se dar apenas no campo da consciência, mas também não poderá acontecer exclusivamente pela prática/ação, correndo o risco de se tornar ativismo puro. É fundamental que seja uma ação "associada a sério empenho de reflexão, para que seja práxis" (Freire, 2013, p. 72), " é preciso, enfatizemos, que se entreguem à práxis libertadora" (Freire, 2013, p. 49), que se assuma o desafio da educação como prática de liberdade, ou seja, que se lute pela formação humana voltada para a certificação da liberdade, da humanidade, da capacidade de entender, de transformar e de criar.

\section{Práxis libertadora}

Para libertar-se, Freire (2013) indica ser essencial, por parte dos homens, a compreensão de suas necessidades, de sua concretude e dos complexos que formam as relações sociais. O que não se trata de "explicar às massas, mas em dialogar com elas sobre a sua ação" (Freire, 2013, p. 55) e sobre a realidade, na perspectiva de promover a inserção crítica em sua realidade "através da práxis, pelo simples fato de nenhuma realidade se transformar a si mesma" (Freire, 2013, p. 55).

A autêntica libertação "não é uma coisa que se deposita nos homens. Não é uma palavra oca, mitificante. É práxis, que implica a ação e reflexão dos homens sobre o mundo para transformá-lo" (Freire, 2013, p. 93). Sem práxis, "é impossível a superação da contradição opressor-oprimido" (Freire, 2013, p. 52).

A luta por liberdade equivale a tornar o homem um ser ativo em relação ao meio e suas circunstâncias, um ser que produz mudanças, transformações em sua consciência e em sua realidade. Portanto, a luta por liberdade torna-se práxis, não a práxis metafísica de Platão (1991) como forma de participação da realidade ideal, mas a práxis política e histórica.

Na obra analisada, Freire destaca a necessidade de um processo de conscientização do ser humano ou uma forma crítica e reflexiva de abordar o mundo, que o afirme como sujeito da práxis. Esse processo 
aparece inserido numa proposta pedagógica e crítica voltada a atender as massas populares, no que se refere à descoberta da realidade opressora e ao nível da afirmação de um compromisso com a transformação prática de tal realidade.

Ao relacionar o princípio filosófico da práxis à realidade para arquitetar, por meio de uma proposta educativa, formas de romper com a ideia de manter a realidade como ela é, ou seja, ao defender a existência do homem enquanto ser histórico e social, inserido no mundo em constante transformação, Freire supera Hegel (1992), para quem a práxis não passa de um momento do processo de autoconsciência do absoluto. Em seu idealismo absoluto, Hegel (1992) entende que o pensar e o agir dos homens sobre seu contexto histórico não devem se ocupar com a transformação de sua realidade. Sua filosofia, portanto, é discordante da concepção de práxis enquanto atividade (trans)formadora.

Ao apresentar a Pedagogia do Oprimido, como pedagogia humanista e libertadora, Freire afirma que, em seu primeiro momento, "os oprimidos vão desvelando o mundo da opressão e vão comprometendo-se na práxis, com a sua transformação" (Freire, 2013, p. 57). Reside aqui a negação da existência de um processo de conscientização fora da práxis, isto é, fora da ação e reflexão como unidades dialetizadas que vão permanentemente (trans)formando o ser humano e seu mundo real.

Na obra em destaque, Freire alerta que, ao defender a reflexão dos oprimidos sobre suas condições concretas, não se pretende desenvolver um jogo divertido de intelectualidade. Para ele, "a reflexão, se realmente reflexão, conduz a prática" (Freire, 2013, p. 73) e, "se o momento já é o da ação, esta se fará autêntica práxis se o saber dela resultante se faz objeto da reflexão crítica" (Freire, 2013, p. 73).

Esclarece ainda que, defendendo a "práxis, a teoria do fazer" (Freire, 2013, p. 172), ele não está "propondo nenhuma dicotomia de que resultasse que este fazer se dividisse em uma etapa de reflexão e outra, distante, de ação. Ação e reflexão se dão simultaneamente" (Freire, 2013, p. 173) e não podem dar-se sem a ação e a reflexão dos outros, se o compromisso da ação dos homens for o da libertação.

Com essa pedagogia alçada na unidade dialética da ação-reflexão, Freire assimila um conceito de práxis que impulsiona a superação do dualismo ação (prática) versus reflexão (teoria), que perpassa a história das tendências pedagógicas e que na sociedade capitalista ganha a forma de antinomia capital-trabalho. Com essa superação, Freire se aproxima da visão de Konder (1992), para o qual a teoria e a prática são elementos interligados, interdependentes. Na obra em análise, Freire apresenta uma práxis educativa constituída enquanto reflexão e ação dos homens sobre o mundo, empenhados em transformá-lo.

A práxis libertadora freireana sucede a tomada de consciência da realidade alicerçada na dialética anúncio-denúncia do contexto históricosocial da América Latina nos anos de 1960-1970, países dependentes, oprimidos, subalternos e inseridos na periferia do capitalismo mundial (Borges, 2013). 
O pensamento de Freire remete à práxis um sentido de atividade questionadora, sugestiva, crítica e também prática, pois visualiza a libertação não somente na abstração, mas em sua objetivação, plasmada nas transformações do homem com a realidade e entre si. Supera o estado de alienação e de inércia imposto pelas relações hegemônicas e opressoras do sistema capitalista.

Corroborando com o pensamento acima, Rossato (2010) assinala que Freire compreende práxis como uma estreita relação estabelecida "entre um modo de interpretar a realidade e a vida e a consequente prática que decorre desta compreensão levando a uma ação transformadora" (p. 325).

Por fim, o sentido de práxis, quando adjetivada por Freire de libertadora, alia-se à interpretação de Sánchez Vázquez (1977) sobre a segunda tese de Feuerbach elaborada por Marx (2007). Nesta obra, a práxis é entendida como uma atividade/ação transformadora, mas ao mesmo tempo teórico (reflexão)-prática (ação). Teórica sem ser essencialmente contemplativa, pois a teoria é a guia da ação e a prática é a ação guiada pela teoria. A teoria não existe à revelia da práxis.

Dito de outra forma, a práxis em Freire remete a uma ação orientada pela teoria que se remete à ação transformadora/libertadora. A práxis aparece significando o "fazer e o saber reflexivo da ação" (Kronbauer, 2010, p. 23). Refere-se a uma atividade prática, imbuída de conhecimentos, reflexões e questionamentos, com vista a ações transformadoras da realidade e do próprio homem.

\section{Práxis autêntica}

Na perspectiva de combater a educação bancária, o estado de depósito de arquivo ao qual os homens foram historicamente submetidos, Freire, no livro em análise, propõe uma educação mediada por uma autêntica práxis educativa, pelo saber autêntico, que pretende transformar a mentalidade das massas, do oprimido, e visa sua inserção crítica no mundo, como transformadores dele, sujeitos ativos, criativos, incompletos, seres de opção, livres para atuar e usar suas faculdades. Para ele, o "desvelamento do mundo e de si mesmas, na práxis autêntica, possibilita às massas populares a sua adesão" (Freire, 2013, p. 229) à luta pela libertação, pelo processo de humanização.

A proposta educativa de Freire (2013, p. 52) baseia-se na práxis autêntica, que não é "'blá-blá-blá', nem ativismo, mas ação e reflexão", que é prática de libertação. Implica a negação do homem enquanto ser teórico, abstrato, isolado, solto, desligado do mundo, vazio e abstraído das relações sociais. Semelhante a Marx (2007), Freire quer situar o homem e seu fenômeno educacional junto às relações sociais e à história da sociedade. Intenciona afirmar a vocação ontológica do homem de humanizar-se. Ser humano, tornar-se humano é uma tarefa sem fim, processo infinito de construção, de formação/educação e reconstrução de si; é busca pelo que ainda não se é. 
Cabe relembrar que a "reflexão que se propõe, por ser autêntica, não é sobre este homem abstração, nem sobre este mundo sem homens, mas sobre os homens em suas relações com o mundo. Relações em que consciência e mundo se dão simultaneamente" (Freire, 2013, p. 98). $\mathrm{Na}$ medida em que os homens vão refletindo, conjuntamente, sobre si e sobre seu mundo, eles aumentam o campo de sua percepção, destacam os percebidos e voltam sua reflexão sobre eles.

No contexto da educação problematizadora, alçada na e pela práxis autêntica, Freire ressalta que a ação do educador "deve estar infundida da profunda crença nos homens" (Freire, 2013, p. 86). Desse modo, reconhece a necessidade de estabelecer entre educador e educando uma relação comunicativa, interativa, dialógica e de companheirismo que propicie a humanização de ambos. Conforme o autor citado, o pensar e o agir do educador somente ganharão autenticidade na autenticidade do pensar e do agir dos educandos, mediatizados pela realidade, pela solidariedade e pelo diálogo. O pensar e o agir de um devem coadunar-se no pensar e no agir do outro, ou seja, a ação de ambos deve ser orientada pela reflexão coletiva.

A proposta educativa elaborada pelo educador pernambucano de "caráter autenticamente reflexivo, implica um constante ato de desvelamento da realidade" (Freire, 2013, p. 97). É coerente, portanto, com a vocação ontológica e histórica dos homens, "como seres que não podem autenticar-se fora da busca" (Freire, 2013, p. 101). Esse movimento da busca, do vir a ser, do ser mais, é histórico e tem seu ponto de partida e objetivo localizados no sujeito. Na verdade, trata-se do movimento de humanização dos homens.

Falar em humanização em Freire é entendê-la como itinerário que possibilita aos homens tomar consciência de si mesmos, de seu pensar e de suas atitudes; desenvolvimento de todas as potencialidades humanas na perspectiva de atender as necessidades coletivas. Recorrendo a Pierre Furter, o educador pernambucano assinala que o humanismo está baseado "em permitir a tomada de consciência de nossa plena humanidade, como condição e obrigação: como situação e projeto" (Furter, 1966, apud Freire, 2013, p. 117). Nesse sentido, Freire registra que a educação autêntica "não se faz de A para B ou de A sobre B, mas de A com B" (Freire, 2013, p. 116). O papel do educador, na perspectiva apontada, passa a ser o de atuar, o de lutar com as massas populares visando à recuperação de sua humanidade roubada, tendo como mediador o diálogo. Sem isso, não é possível práxis autêntica nem para A nem para B.

O reconhecimento dos homens como seres inacabados, inconclusos e históricos fez Freire entender que educação é um quer fazer permanente e coletivo. "Permanentemente, na razão da inconclusão dos homens e do devenir da realidade. Desta maneira, a educação se re-faz constantemente na práxis" (Freire, 2013, p. 102). Portanto, a defesa de uma autêntica práxis educativa, diferente da educação "bancária", "imobilista", "fixista", em Pedagogia do Oprimido, tem como pressuposto a necessidade de uma concepção de educação envolvida numa relação orgânica com o contexto 
histórico e social. Por sua vez, correspondente à condição dos homens como seres históricos e à sua historicidade.

Diante do exposto, acreditamos que o sentido da práxis autêntica defendida por Freire a revela como aquela que está a serviço do processo de humanização. Essa ideia se entrelaça com o pensamento de Soares (2007), que coloca a práxis como eixo central da verdadeira elevação humana sobre sua própria desumanidade. Mostra-se compatível com a vocação ontológica e histórica de ser mais do homem. Nessa esteira, a práxis autêntica apresentada por Freire na obra analisada cria, forma e auto(trans)forma a essência humana. Torna-se o alicerce, a égide sobre a qual se desenvolve o processo histórico de promoção da humanidade dos homens.

\section{Práxis revolucionária}

Refletindo sobre suas práticas vivenciadas no Brasil e no Chile, Freire elabora uma proposta educativa que tem como compromisso central a libertação humana, construída no diálogo e na luta por transformações sociais. Ele, em Pedagogia do Oprimido, quer afirmar que a consciência de transformação da realidade e de educação só se obtém por meio da práxis revolucionária.

Portanto, encontramos, na obra citada, ideias pedagógicas voltadas para a práxis que se quer revolucionária. Segundo o educador pernambucano, "não há revolução com verbalismos, nem tão pouco ativismo, mas com práxis, com reflexão e ação incidindo sobre as estruturas a serem transformadas" (Freire, 2013, p. 169).

Ao articular práxis à revolução, Freire (2013, p. 169) descreve a impossibilidade de ter "a manipulação, a sloganização, o 'depósito', a condução, a prescrição, ${ }^{2}$ como constituintes da práxis revolucionária. Precisamente porque o são da dominadora". Também reafirma que a educação bancária não está a serviço dos interesses das massas populares e coloca a práxis revolucionária em oposição ao quefazer dominador, "práxis" não autêntica. Em sua percepção, a práxis revolucionária se opõe ao quefazer das elites dominadoras; e é natural que assim seja, pois são quefazeres antagônicos (Freire, 2013). O quefazer revolucionário é humanista, já o quefazer opressor não o é, objetiva-se na absolutização da ignorância das massas (Freire, 2013).

Por outro lado, Freire (2013) defende que o quefazer revolucionário é um processo de profundas e radicais transformações - implica dizer, fundado no processo de humanização e que remete para as intervenções do homem social no mundo real. A primeira radicalização, segundo Freire, é o combate ao assalto desumanizante da palavra.

Ele indica que o desvelamento do mundo da opressão se instaura

A manipulação, a sloganização, o "depósito", a condução, a prescrição são características apresentadas por Freire da educação bancária. pela reconquista do direito de pronunciar o verbo, pelo questionamento, pela dúvida. "Esse processo só pode ser construído na sua dialogicidade, com e jamais para o povo. É busca, desejo, esperança e luta de todos que, em comunhão, fazem sua história de libertação" (Schnorr, 2001, p. 73). 
Atento às contribuições de Marx (2007) na terceira Tese de Feuerbach, em que se afirma a necessidade de os educadores se educarem, Freire (2013) entende que é pela relação dialógica entre lideranças e massas (educador e educandos), mediada pelos conhecimentos que ambos possuem e problematizam, que se afirma a liberdade uns dos outros. A revolução educativa e cultural proposta por Freire implica a compreensão de que o líder, o educador, não é dono do saber e não deve impor seus conhecimentos ao povo, mas é aquele capaz de aprender enquanto ensina, que se autoafirme liberto, propiciando coletivamente a liberdade de outras pessoas, pois, afinal, "ninguém liberta ninguém, ninguém se liberta sozinho: os homens se libertam em comunhão" (Freire, 2013, p. 71).

Em comunhão não há dominação, não há opressor e oprimidos, mas igualdade para todos. Assim, os homens exercem sua práxis em plenitude, resgatam o direito à palavra, revolucionam, rompem as estruturas de uma sociedade injusta e desigual. Dessa coerência, decorre a práxis revolucionária dos educandos e educadores numa ação transformadora, tornando a história um devir constante.

Conscientes e cointencionados à realidade, lideranças e massas se encontram como sujeitos do ato de conhecer a realidade de forma crítica, desvelando-a; assumem seu lugar no mundo real. Assim, Freire (2013) dignifica educadores e educandos, líderes revolucionários e massas populares como sujeitos do fazer educativo. Desse modo, o trabalho educativo, no sentido amplo, presente na obra em análise, vem contribuir para o processo revolucionário, antes mesmo de a transformação ocorrer, ao somar formação humana e luta política.

Sousa Júnior (2010, p. 31) assinala que:

A revolução é autotransformação do homem, é práxis humana, atividade finalista que intervém transformando as circunstâncias em relação com as quais o homem se constrói. Uma nova consciência só será possível se houver uma transformação do homem, e esse homem transformador, a partir do qual pode surgir a nova consciência, apenas através de um movimento prático revolucionário é que poderá emergir historicamente. Desnecessário lembrar que o homem novo e a nova consciência são interdependentes e ambos se constroem no processo educativo da práxis revolucionária.

A revolução, portanto, atua como atividade transformadora das circunstâncias e contribui para os processos educativos dos homens. Daí, pode-se reafirmar que o trabalho educativo de Freire colabora significativamente para o processo revolucionário, uma vez que prima pelas transformações das circunstâncias opressoras e desumanizantes, na perspectiva de desenvolver, de formar um homem não alienado.

Nesse quadro, reconhecemos que Freire (2013) ingressa sua práxis na esfera da luta política, favorecendo o desenvolvimento da consciência política "enquanto processo de reconhecimento dialético e intersubjetivo que impele a práxis" (Torres, 1979, p. 23).

A práxis educativa de Freire, se quer revolucionária, aparece associada a um contexto histórico, social e político conturbado, alienante, opressor 
e altamente desumanizante. Suas contribuições teóricas e práticas visam favorecer os homens, em geral, e as massas populares, em específico, no intuito de se constituírem em seres para si e lutarem por sua liberdade, pela emancipação da humanidade.

A nosso ver, Freire (2013) atribui à práxis revolucionária um papel político-educativo fundamental para o processo de formação ampla do homem. Ele nos ajuda a entender que a educação deve partir da realidade para compreender o homem e ser posta a seu serviço, que seu objetivo deve ser a compreensão e a interpretação do papel dos homens no mundo. Por isso, a prática educativa torna-se um ato político, pois ela pode mostrar ou ocultar a realidade.

Portanto, a práxis revolucionária em Freire (2013) implica a denúncia da opressão e o anúncio de novas possibilidades feitos de maneira crítica, reflexiva, criativa e coletiva contra as estruturas de opressão, como o imperialismo e o patriarcado; a reafirmação de homem enquanto um ser em permanente processo de desenvolvimento e de aprendizagem; e a elucidação dos alcances políticos da ação educativa.

\section{Práxis verdadeira}

Para Freire (2013, p. 108), os homens se fazem, (trans)formam-se "na palavra, no trabalho e na ação-reflexão". Ele entende que as ações do homem sobre a natureza e o mundo social, ou seja, sobre a realidade em geral, implicam criação, objetivação. Sendo elas guiadas pela práxis verdadeira, expressada pela palavra, pelo trabalho e pela ação-reflexão do mundo e do próprio homem, criam o domínio da cultura e da história, tornam-se fonte de conhecimento crítico, reflexivo e criativo, revelando, assim, o caráter ontocriativo do processo histórico de (trans)formação do homem.

Contudo, na realidade social, objetiva, que não existe por acaso, mas como produto da ação dos homens, pode-se constatar a negação e a inversão da práxis (Freire, 2013).

Cientes desse fato, os opressores para dominar "não têm outro caminho senão negar às massas populares a práxis verdadeira. Negar-lhes o direito de dizer suas palavras, de pensar certo" (Freire, 2013, p. 170), de perceber criticamente o mundo, de elevar sua consciência em torno da realidade opressora, desumana. Se essa realidade, produto da ação dos homens, "na 'inversão da práxis', se volta sobre eles e os condiciona" (Freire, 2013, p. 51), implicando a existência dos que oprimem e dos que são oprimidos, cabe a estes lutar por sua libertação e transformação da realidade opressora mediante a práxis.

A "inversão da práxis" atua como semeadora da alienação, não só das relações sociais e políticas, mas também daquelas que envolvem a atividade produtiva do trabalho. É comprada sua força de criar, de produzir, que significa a venda de si mesmo, de sua práxis, de sua humanidade. 
Na contramão da recusa e da inversão da práxis, Freire aponta, na obra em relevo, que transformar a realidade opressora é tarefa histórica dos homens. Fazendo-se necessária a luta por sua libertação. Daí, o esforço sério, profundo e coletivo no processo de conscientização/humanização dos homens por meio de uma práxis verdadeira que os faça desmitificar a realidade e superar o estado de objetos, de dominados, assumindo o papel de sujeitos da história. Alertamos que o processo de humanização, reclamado por Freire, mesmo orientado pela práxis verdadeira, não é algo simples e homogêneo.

A práxis verdadeira, à qual Freire se refere, "opõe-se às ideias de alienação e domesticação, gerando um processo de atuação consciente que conduza a um discurso sobre a realidade para modificar esta mesma realidade" (Rossato, 2010, p. 325). Conscientes (superado o estado de alienação), os homens vão desvelando a necessidade de exercerem "um ato de adesão à práxis verdadeira de transformação da realidade injusta" (Rossato, 2010, p. 237). Essa mudança qualitativa da percepção histórica do mundo, "que não se realiza fora da práxis, não pode jamais ser estimulada pelos opressores, como um objetivo de sua teoria da ação" (Freire, 2013, p. 207).

Daí a importância de permitir, incentivar e propiciar aos homens, não como privilégio, mas como seu direito universal, a ação de proferir, de dizer a palavra verdadeira. Freire nos aponta que se trata da palavra que (trans) forma e recria o mundo. Para ele, "não há palavra verdadeira que não seja práxis" (Freire, 2013, p. 107). Esta "sendo reflexão e ação verdadeiramente transformadora da realidade, é fonte de conhecimento reflexivo e criação" (Freire, 2013, p. 127). Então as atividades realizadas pelos homens, como seres da práxis, implicam fonte de (trans)formação, de criação, o que não ocorre com os demais animais.

A libertação histórica, portanto, visa à superação das alienações que se opõem ao ser, ao combate às tentativas de inverter e negar aos homens o verdadeiro sentido da práxis. Pelo diálogo, pelo trabalho e pela açãoreflexão dos homens em coletividade, forja-se sua própria conscientização e as dos demais homens, brota a necessidade e o reconhecimento da transformação da realidade injusta. Logo, a conscientização vai se "aprofundando na práxis criadora de uma sociedade nova" (Freire, 2013, p. 215), de uma nova realidade.

Diante dos termos apresentados, ao tratar da práxis verdadeira, Freire (2013) remete a um caráter criativo da práxis humana. Nesse sentido, ele vai ao encontro do pensamento de Paulo Netto e Braz (2010), no qual identificam a práxis enquanto revelação do homem como ser criativo e autoprodutivo. Como seres da práxis, dizem os autores mencionados, os homens são produto e criação da sua autoatividade.

Nessa perspectiva, Sánchez Vázquez (1977, p. 247) nos diz que do "ponto-de-vista da práxis humana, total, que se traduz na produção ou autocriação do próprio homem, a práxis criadora é determinante, já que é exatamente ela que lhe permite enfrentar novas necessidades, novas situações". O ser humano encontra-se em um constante movimento 
criativo provocado pelas necessidades cotidianas, pelas novas situações ou problemas enfrentados. Mesmo tendo encontrado uma solução para determinada situação ou problema, não lhe é suficiente repeti-la eternamente, pois ela terá validade até o momento em que novas situações passem a exigir adequações ou outras soluções. Criar, pois, é a mais vital necessidade humana, porque só criando o homem vai fazendo o mundo e constituindo-se.

A expressão criativa relacionada à práxis verdadeira se faz válida não apenas porque carrega implícita a autoafirmação do ser humano enquanto sujeito do mundo e a transformação da realidade, mas pela relação direta que guarda com a própria aquisição de conhecimento, possibilitada no desenvolvimento das práticas pedagógicas sugeridas pelo autor do livro em análise.

No contexto de uma práxis educacional libertadora, humanista, reflexiva e revolucionária, criar supõe a não sujeição a formas mecânicas, aos depósitos, às repetições e às memorizações, práticas comuns da escola tradicional. "Nesta distorcida visão da educação, não há criatividade, não há transformação, não há saber. Só existe saber na invenção, na reinvenção, na busca inquieta, impaciente, que os homens fazem no mundo, com o mundo e com os outros" (Freire, 2013, p. 81). Nessa perspectiva, a expressão criadora é, em síntese, a possibilidade de oferecer aos educandos, aos homens em geral, alternativas renovadas e permanentes. É o aspecto que diferencia a concepção "bancária" de educação da concepção libertadora.

Por fim, Freire (2013), ao conceber o homem como ser de vocação ontológica e histórica de ser mais e ao relacionar a expressão criativa com práxis, aproxima-se do sentido de práxis proporcionado por Kosík (1976), enquanto revelação do segredo do homem como ser ontocriativo, que cria a realidade e a compreende em sua totalidade. Assim, o referido autor remete a uma ideia de práxis enquanto atividade que historicamente cria a realidade e o homem e reafirma a práxis enquanto atividade/ação essencialmente criativa.

\section{Considerações finais}

Na obra analisada, Freire se arma de uma teoria da ação dialógica, reflexiva e problematizadora que favorece a luta contra propostas de formação/educação enrijecida pela burocracia, pelo dirigismo, distante da realidade, descontextualizada, não passível de reflexão e verticalizada, desconectada da totalidade dos processos educativos. Instrumentaliza a luta em defesa de processos formativos alçados nos princípios da humanização, os quais devem ultrapassar os muros das instituições incumbidas dessa missão, devem abranger a vida em todos os seus aspectos, tendo que favorecer a compreensão de que não se é objeto e sim sujeito. Por fim, Freire vem ponderar sobre a necessidade de se lutar por mudanças sociais, pela reafirmação da vocação onto-histórica dos homens de ser mais, de se fazerem seres históricos e sociais, de se constituírem sujeitos da práxis. 
Práxis, em Pedagogia do Oprimido, é entendida como reflexão sobre ação em determinado contexto, lugar e espaço, com vistas à transformação da realidade e dos processos de resgate e de formação da humanidade. Freire entende a práxis em sua amplitude. Não a reduz somente à prática social, pois se trata de uma categoria totalizante e ativa que, além de incluir o contexto social, contempla as práticas econômicas, políticas, ideológicas e teóricas. Nesse sentido, Freire não a entende como categoria inerte, exânime, desvanecida do real e inconsciente.

As leituras nos auxiliaram no entendimento de que a práxis referenciada na obra Pedagogia do Oprimido nasce da coerência entre a palavra e a ação dos homens, em geral, e, em específico, dos educadores e líderes revolucionários. Surge como palavra viva, dinâmica, que diz e transforma o mundo real, que flui da ação, do fazer história e da historicidade dos homens.

Na perspectiva de Freire, os educadores devem compreender a educação mediante a realidade social do ser humano, colocando-a, assim, a serviço do processo de humanização do homem, desmascarando, desmitificando e escamoteando a realidade. Por isso, a defesa de uma educação comprometida politicamente com as massas populares. As opções políticas dos educadores se apresentam nas suas ações, princípios e métodos empregados. Pronunciar a palavra, para Freire, é pronunciar o mundo, é definir o lugar na história enquanto sujeito - que é agente, ser da práxis e, por sua vez, homem teórico-prático.

No decorrer desta análise, compreendemos que, segundo Freire, não pode haver dicotomia entre teoria e prática. Para o educador, o pensar e o agir estão intrinsecamente vinculados. É na ação e reflexão, na palavra e no agir. É pela ação dialógica que se chega à tomada de consciência da situação vivida. No tocante à práxis, o pensamento freireano supera a oposição ou a contradição teoria e prática, situando na realidade concreta do ser humano, ou melhor, da atividade humana, o poder de transformação da realidade e do próprio ser humano. É uma dialética que conduz a uma ação prática no processo que leva ao conhecimento da realidade a ser transformada. A práxis, vista desse modo por Freire, é um produto histórico-social do ser humano, situado no mundo, em um processo contínuo de transformação.

As ideias de Freire defendem o estabelecimento da unidade entre ação-reflexão e realizam a denúncia do sistema capitalista como perverso, desumano, excludente, opressor. Os fenômenos histórico-sociais não somente no Brasil, mas em toda a América Latina nas décadas de 1960 e 1970, são percebidos por Freire sob a perspectiva da contradição opressoroprimido, com base em uma visão de ser humano contextualizada em seu meio social, lugar por excelência da práxis.

Ao afirmar sua crença nos homens, Freire nos ensina que, enquanto houver seres humanos e, portanto, história, a humanização, o encontro dos homens com a sua essência, a consagração da vocação ontológica do homem poderão tornar-se fato. Trata-se, a nosso ver, da ideia de homem que, pelo conjunto de suas práticas, produz, simultaneamente, objetos 
e a si mesmo em resposta à necessidade do próprio ser humano de se constituir como tal, na cotidianidade da vida histórico-social.

Freire coloca a práxis como o foco central para se chegar à verdadeira assunção humana sobre sua própria desumanidade. Assim, a práxis se traduz em fonte abundante para que os homens conheçam sua verdadeira condição, ou melhor, os fundamentos ontológicos de sua existência.

Ao relacionar a categoria filosófica da práxis à realidade, Freire visa romper com a ideia de mundo imutável, ou seja, defende a existência do homem inserido no mundo em constante transformação; remete à práxis num sentido de atividade questionadora, sugestiva, reflexiva e prática, que objetiva a libertação dos homens do estado de alienação, da inércia diante das relações determinadas pela classe dominante, hegemônica e opressora do sistema capitalista. Dito de outra forma, Freire refere-se à práxis como ação transformadora e libertadora, como atividade prática, alicerçada em conhecimento, questionamentos e reflexões com vistas às ações transformadoras da realidade e do homem, propiciando a esse o direito de fazer sua história de libertação.

Em síntese, Freire, didaticamente, destaca a práxis, justifica sua amplitude e importância dentro da proposta educativa da Pedagogia do Oprimido. Para isso, ele a qualifica como: 1) práxis libertadora constituída pela superação do dualismo entre ação e reflexão e refere-se a uma atividade prática, orientada pela teoria que se remete à ação transformadora da realidade, por sua vez, libertadora do homem; 2) práxis autêntica - promove, cria, forma e auto(trans)forma a essência humana, está a serviço do processo histórico de promoção da humanidade; 3) práxis revolucionária - implica o desvelamento do mundo da opressão pelo diálogo com os oprimidos, com vista ao reconhecimento dos seres humanos como seres de busca, do ser mais; 4) práxis verdadeira - revela o caráter criativo e autoprodutivo da práxis humana. Origina na ideia de homem enquanto produto e criação de sua autoatividade.

Diante dessas considerações, compreendemos que se prepondera, nos sentidos de práxis para Freire, seu caráter político, possibilitador do processo de conscientização dos homens e orientador de suas ações sobre o mundo real, com vistas à sua transformação.

A práxis em Freire remete ainda à ideia de um conjunto de práticas visando à transformação da realidade e à produção da história. O que nos leva a entender que é sobre o tripé formado pela transformação de uma realidade injusta, pela transformação baseada em uma crítica dessa realidade e pelo seu conhecimento que o citado autor, assim como Sánchez Vázquez (1977), elabora uma noção de práxis histórica e social. Reconhecemos em Freire a concepção de que a objetivação da práxis humana, o resultado da ação transformadora do homem sobre a realidade, é o legado, a herança deixada ao assumirem os homens seu papel na história. A história da humanidade, nessa perspectiva, torna-se a da práxis humana.

Portanto, compreendemos que de modo geral encontramos, na obra em estudo, sentidos e significados de uma práxis que promove a união da relação dialética entre ação e reflexão sobre a realidade transformadora 
das condições reais de opressão, alienação e dominação, por isso, libertadora; uma práxis desveladora da realidade e, ao mesmo tempo, fonte perene do processo contínuo de (re)construção, de formação/educação do homem, ou seja, do processo de humanização dos homens; uma práxis articulada à revolução, a profundas e radicais transformações, dando ênfase para a ação dialógica e política junto às massas populares na perspectiva de sua conscientização, de sua inserção crítica na realidade; e, ainda, de uma práxis humana verdadeiramente criativa, que, em síntese, é o oferecimento aos homens de permanentes oportunidades de renovação de sua vida, de suas práticas sociais, produtivas, educativas e políticas, de novas aprendizagens, de novas invenções enquanto sujeito da história.

\section{Referências bibliográficas}

BEISIEGEL, C. R. Paulo Freire. Recife: Fundação Joaquim Nabuco; Massangana, 2010. (Coleção Educadores).

BORGES, V. A reconstrução de uma ética pedagógica libertadora à luz de Paulo Freire. Curitiba: CRV, 2013.

BRANDÃO, C. R. O que é educação. São Paulo: Brasiliense, 2007.

FREIRE, P. Pedagogia da esperança: um reencontro com a pedagogia do oprimido. Rio de Janeiro: Paz e Terra, 1992.

FREIRE, P. Pedagogia do oprimido. 54. ed. Rio de Janeiro: Paz e Terra, 2013.

GADOTTI, M. Paulo Freire: uma biobibliografia. São Paulo: Cortez, 1996.

GUTIÉRREZ, F. Educação como práxis política. São Paulo: Summus, 1988.

HEGEL, G. W. F. A fenomenologia do espírito. São Paulo: Nova Cultural, 1992. (Os Pensadores).

KONDER, L. O futuro da filosofia da práxis: o pensamento de Marx no século XXI. Rio de Janeiro: Paz e Terra, 1992.

KOSÍK, K. Dialética do concreto. 4. ed. Rio de Janeiro: Paz e Terra, 1976.

KRONBAUER, L. G. Ação-reflexão. In: STRECK, D. R.; REDIN, E.;

ZITKOSKI, J. J. Dicionário Paulo Freire. Belo Horizonte: Autêntica, 2010. p. 23-24.

MARX, K. Teses sobre Feuerbach. In: MARX, K.; ENGELS, F. A ideologia alemã. Tradução de Marcelo Backes. Rio de Janeiro: Civilização Brasileira, 2007. p. 611-613. 
PAULO NETTO, J.; BRAZ, M. Economia política: uma introdução crítica. 6. ed. São Paulo: Cortez, 2010.

PIO, P. M. A práxis em Pedagogia do Oprimido: lições pedagógicas e políticas. 2015. 105f. Dissertação (Mestrado Acadêmico Intercampi em Educação e Ensino) - Faculdade de Filosofia Dom Aureliano Matos, Faculdade de Educação Ciências e Letras do Sertão Central, Universidade Estadual do Ceará, Limoeiro do Norte, 2015.

PLATÃO. Diálogos. 5. ed. São Paulo: Nova Cultural, 1991. (Os Pensadores).

ROSSATO, R. Práxis. In: STRECK, D. R.; REDIN, E.; ZITKOSKI, J. J. Dicionário Paulo Freire. Belo Horizonte: Autêntica, 2010. p. 325-327.

SÁNCHEZ VÁZQUEZ, A. S. Filosofia da práxis. 2. ed. Rio de Janeiro: Paz e Terra, 1977.

SAVIANI, D. História das ideias pedagógicas no Brasil. Campinas: Autores Associados, 2007.

SCHNORR, G. M. Pedagogia do oprimido. In: SOUZA, A. I. (Org.). Paulo Freire: vida e obra. São Paulo: Expressão Popular, 2001. p. 69-100.

SOARES, R. Apontamentos críticos contra o pragmatismo e a favor da filosofia da práxis. In: JIMENES, S. et al. (Org.). Contra o pragmatismo e a favor da filosofia da práxis: uma coletânea de estudos classistas. Fortaleza: Ed. da UECE, 2007. p. 29-45.

SOUSA JÚNIOR, J. Marx e a crítica da educação: da expansão liberaldemocrática à crise regressivo-destrutiva do capital. Aparecida, SP: Ideias \& Letras, 2010.

SOUZA, A. I. Educação e atualidade brasileira: a emersão do povo na história. In: SOUZA, A. I. (Org.). Paulo Freire: vida e obra. São Paulo: Expressão Popular, 2001. p. 33-68.

TORRES, C. A. A práxis educativa de Paulo Freire. São Paulo: Loyola, 1979.

Recebido em 11 de maio de 2016.

Solicitação de correções em 10 de novembro de 2016

Aprovado em $1^{\circ}$ de dezembro de 2016. 